\title{
Managerial Tenure And Mutual Fund Performance: Evidence From Index Funds
}

Demissew Diro Ejara, University of New Haven, USA

Raja Nag, New York Institute of Technology, USA

\begin{abstract}
We analyze the impact of managerial tenure on the performance of mutual funds. We examine different aspects of the mutual funds and relate them to managerial tenure. We control for risk, asset allocation (North America and Emerging Markets), size, turnover and number of holdings. Based on a sample of index mutual funds, we find that managerial tenure has significant impact of the funds return. The strength of this relation diminishes as performance is measured on longer term basis. There is no significant direct impact of managerial tenure on expense ratio and rating.
\end{abstract}

Keywords: Mutual funds, managerial tenure, mutual fund rating, risk, return

\section{INTRODUCTION}

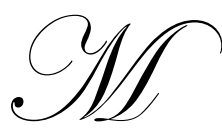

utual funds provide the opportunity to diversify investment without the investor going through securities selection process. The extent of risk diversification and the return performance of mutual funds depend on various factors including number of holdings, style, asset allocation, expense ratio, turnover and several other factors. The focus of this paper is on the impact of managerial tenure on mutual fund performance. Managers with longer tenure may follow investment strategy with long-term view than managers with shorter tenure.

There are numerous studies on mutual fund performance, but very few are on the impact of managerial tenure. The limited studies on managerial tenure report conflicting results. Chevalier and Ellison (1999) and Fortin, et. al. (1999) find no significant relations between managerial tenure and mutual fund performance. Peterson, et.al. (2001) find negative relations, and attribute it to possible entrenchment or aging. Filbeck and Tomkins (2004) and Ferreira, et. al. (2006) find positive relations between managerial tenure and mutual fund performance. Those who find positive relations between managerial tenure and mutual fund performance attribute the result to the learning effect of experienced managers. The different studies differ in terms of performance measurement, sample, period covered, and model used. Some measure return by using excess return after adjusting for market risk, Fama-French factors and even momentum. But some of these factors are endogenous and managerial decisions may affect them. Risk, for example, depends on the manager's allocation decision and fund style. For most of the studies the sample sizes and sample periods differ.

We analyze the relationship between managerial tenure and mutual fund performance based on index funds. Index funds try to mimic some established market indices and are therefore relatively passive investments. Stock picking and market timing abilities are less apparent in the case of index funds than in the more actively managed mutual funds. Index funds provide the opportunity to test the impact of managerial tenure. The results will also be cleaner than mixing mutual fund samples of different characteristics. Our results support the view that managerial tenure positively affects mutual fund performance. There is no direct impact of managerial tenure on expense ratio and ratings of the fund.

The rest of the paper is organized as follows. Section 2 describes the model of analysis we use. Section 3 describes the sample and provides some descriptive analyses. Section 4 presents results of the regression analyses and section 5 concludes. 


\section{MODEL}

We use some descriptive statistics and regression analysis to test the impact of managerial tenure on mutual fund performance. We measure performance by using Morningstar's average annualized returns over three, five and ten years. This ensures that we take into account, the short, intermediate and long-term performances. Unlike actual yearly returns, the annualized average is less sensitive to idiosyncratic variations in the market caused by factors such as investor sentiment.

Managerial tenure is measured as the average tenure of managers for each fund as compiled by Morningstar. We control for risk, asset allocation, turnover, size, number of holdings and operating fundamentals such as price-to-earnings ratios. We estimate the following regression equation for returns.

$$
\begin{gathered}
R_{i}=\beta_{\mathrm{O}}+\beta_{1} S D_{i}+\beta_{2} N H_{i}+\beta_{3} T_{10}+\beta_{4} T R_{i}+\beta_{5} P E_{i}+\beta_{6} A N A_{i}+ \\
\beta_{7} A E M_{i}+\beta_{8} N A V_{i}+\beta_{9} M T_{i}+\varepsilon_{i}
\end{gathered}
$$

\begin{tabular}{|c|l|}
\hline Variable & \multicolumn{1}{c|}{ Description } \\
\hline$R$ & Average annualized return measured over three, five and ten years (\%) \\
\hline$S D$ & Standard deviation of returns measured over corresponding periods (\%) \\
\hline$N H$ & Total number of holdings \\
\hline$T 10$ & Percent of assets in Top 10 holdings \\
\hline$T R$ & Turnover ratio (\%) \\
\hline$P E$ & Price-earnings ratio, based on average for the holdings \\
\hline$A N A$ & Percent allocation to North America \\
\hline$A E M$ & Percent allocation to emerging markets \\
\hline$N A V$ & Net asset value in millions of dollars (size) \\
\hline$M T$ & Managerial tenure in years \\
\hline$\varepsilon$ & Random error assumed to be normal \\
\hline$\beta$ & Constants \\
\hline Subscript $i$ & Mutual fund identification \\
\hline
\end{tabular}
follows.

We estimate separate regressions for expense ratio (ER) and Morningstar ratings (MSTAR) of the funds as

$$
\begin{aligned}
& E R_{i}=\alpha_{0}+\alpha_{1} S D_{i}+\alpha_{2} N H_{i}+\alpha_{3} \mathrm{T1O}_{i}+\alpha_{4} \mathrm{TR}_{i}+\alpha_{5} P E_{i}+\alpha_{6} A \mathrm{NA}_{i}+ \\
& \alpha_{7} \mathrm{AEM}_{i}+\alpha_{8} N A V_{i}+\alpha_{9} M T_{i}+\omega_{i} \\
& M S T A R_{i}=\delta_{0}+\delta_{1} S D_{i}+\delta_{2} N M_{i}+\delta_{3} T O_{i}+\delta_{4} T R_{i} \\
& +\delta_{5} P E_{i}+\delta_{6} A N A_{i}+\delta_{7} A E M M_{i} \\
& +\delta_{8} N A V_{i}+\delta_{9} M T_{i}+\delta_{10} E R_{i}+\nu_{i}
\end{aligned}
$$

Where $\alpha$ and $\delta$ are constants and $\omega$ and $v$ are random error terms.

The coefficients $\beta_{9}$ in Equation (1), $\alpha_{9}$ in Equation (2) and $\delta_{9}$ in Equation (3) measure the impact of managerial tenure on returns, expense ratio, and rating, respectively. We expect $\beta_{9}$ to be positive, $\alpha_{9}$ to be negative and $\delta_{9}$ to be positive. Managers with longer tenure achieve higher returns, reduce expense ratio and earn higher ratings for the fund. Our empirical results support this hypothesis.

\section{SAMPLE AND DATA}

List of index mutual funds and all the data items used in this study are obtained from Morningstar's Principia database. Principia is a comprehensive database of mutual funds. There are more than twenty-four 
thousand mutual funds listed in Principia. There are 1,255 index funds in the list as of the end of June 2007. Several were excluded because they don't report managerial tenure. There are 1096 that report managerial tenure. Still many of these have missing data points with respect to several other variables. Because of these factors, the sample sizes differ in the analyses that follow.

Table 1 presents descriptive statistics of the variables for the index funds included in our sample. The average annual returns of the funds in the sample are $11.85 \%, 9.12 \%$ and $8.57 \%$ over three, five and ten years respectively. The corresponding median values are slightly lower. Investor average annualized returns, which are returns from the investor point of view incorporating cash inflows and outflows, average $11.49 \%, 9.46 \%$ and $7.71 \%$ respectively over three, five and ten years.

The funds average audited expense ratio is $0.65 \%$. The average turnover rate is $56 \%$ with median turnover of $14 \%$. Although there are some funds with very high turnovers of $1299 \%$ (the maximum) these figures indicate that most of the index funds are passive investments. The price earnings (P/E) ratio averages 18.05 times and the price to book value (P/B) ratio averages 2.85 times. These figures are based on the stocks included in each fund.

Morningstar ratings of the funds vary from one star (worst) to five stars (best). The average rating for the funds in the sample is 2.96 with median of 3. Standard deviations of annualized returns average $9.61 \%, 13.7 \%$ and $15.19 \%$ for three, five and ten years respectively. Returns over longer periods of time show greater dispersion than returns measured over shorter periods.

The average net asset value of the funds in the sample is $\$ 1,213.63$ million with median of $\$ 114.25$ million. There is a large dispersion in size. Some of the funds are very large. The total security holdings of the funds average 583 (with median of 403). The holdings varied from a minimum of one security to a maximum of 10,465 securities. On the average, the funds allocated about $33 \%$ to their top ten holdings. A greater proportion of the funds assets are allocated to US stocks (about 70\%) followed by non-US stocks (16.65\%). Bonds, cash and other assets take the rest of the allocations. Allocation to North American markets constitutes $81.2 \%$ and allocation to developed markets averages more than $98 \%$, which leaves an average of less than $2 \%$ allocation to emerging markets. But there are some funds with larger percentage allocations to emerging market assets.

Table 2 presents variations of mutual fund variables by managerial tenure. Managerial tenure is grouped into four quartile classes and average values of the variables are presented for comparison for each class. There are statistically significant inter-quartile differences in the 3-year and 10-year annualized returns. But the variations are not monotonic. In fact as Figures 1 and 2 show, mutual fund returns are slightly $U$ shaped in managerial tenure. The variations for 5-year annualized returns and investor annualized returns are not significant. Audited expense ratio, turnover ratio and $\mathrm{P} / \mathrm{B}$ ratio show statistically significant variations across managerial tenure quartiles, but only the $\mathrm{P} / \mathrm{B}$ ratio shows a systematic negative relation with managerial tenure.

Standard deviation of returns varies significantly for the 10-year annualized returns. Net assets, number of holdings, and some of the allocation variables by asset class and markets vary significantly, but none of them show systematic patterns. The next section presents the impact of these variables in a multiple regression model.

\section{REGRESSION ANALYSIS}

Table 3 presents results of the regression of mutual fund returns on several variables, including average manager tenure. Returns are average annualized returns over three, five and ten years. Managerial tenure has statistically significant positive impact on performance measured over three and five years, but the coefficient for the ten year annualized return is statistically insignificant. This implies differences in the strength of impact of managerial tenure.

The fundamental variables such as risk, measured by standard deviation of returns, have significant positive impact on returns. This is consistent with established risk-return relationship. The higher the risk, the higher should be the return. Total number of holdings has significant positive impact in the five and ten year return regressions, but negative and insignificant coefficient in the three year return regression. Total number of holdings measures the 
extent to which the fund is diversified. The result implies that well diversified portfolios perform better in the long run, while in the short run, diversification does not have significant impact on return. This seems to be driven by allocation to the top ten holdings. Greater allocation to the top ten holdings results in higher returns over ten years but insignificant impact on three and five year returns.

Turnover ratio and price-to-book ratio have significant negative coefficients in the three and five year return regressions and insignificant negative coefficients in the ten year return regression. High turn over increases transaction costs and reduces return. Similarly, funds with high P/E ratio under perform those with low P/E ratio. High P/E funds are growth funds and low P/E funds are value funds. Value funds outperform growth funds since growth funds are priced high relative to the earnings they generate (see Haugen, 1999).

The percent allocation to North American markets has significant negative impact on returns over three and five years but significant positive impact on returns over ten years. Percentage allocation to emerging markets has the direct opposite impact. The stable North American investment opportunity set offers higher return in the longrun while the high growth emerging markets offer higher return in the short-run. Size measured by net asset value has no significant impact on returns.

In general, the regression analyses of returns show that funds that allow managers longer tenure perform better than those with shorter tenure. This positive impact loses significance over longer periods. Other fundamental variables have results consistent with established theories.

Table 4 presents regression results of audited expense ratio and Morningstar ratings. Managerial tenure has no significant impact on both the expense ratio and Morningstar rating of the mutual funds. This could be due to the fact that the sample is made up of index funds with passive strategy. Passive strategy does not entail frequent rebalancing and hence result in low turnover and stable expense ratio that a manager may not change discretely.

Risk, measured by standard deviation, and turnover ratio have significant positive effects on expense ratio. Number of holdings, allocations to North America and to emerging markets, and the net asset value (size) have significant negative impact on expense ratio. Total number of holdings has positive impact on Morningstar ratings. This indicates that the ratings value diversification. Allocations to both North America and to emerging markets have negative impact on rating. Expense ratio has significant negative effect on rating.

\section{CONCLUSION}

Previous studies report mixed results about the impact of managerial tenure on performance of mutual funds. Based on a sample of index funds, we find that managerial tenure has positive impact on mutual fund performance. The impact on three and five year annualized returns is statistically significant. The impact on ten year annualized return is positive but statistically insignificant. This implies that while experience and the ability to plan on longer term basis helps managers increase returns, the influence of such tenure decreases when we consider very long time horizons.

We control for other factors that affect performance such as risk, allocation, turnover, $\mathrm{P} / \mathrm{E}$ ratio and size. Size, measured by net asset value, has no significant impact on returns. This is inconsistent with previous studies that find scale advantage in large size mutual funds. Allocation to emerging markets has positive impact on short and intermediate term returns and negative impact on longer term returns. Allocation to North America has the opposite impact. High P/E and high turn over have negative relations with returns.

Managerial tenure has no significant impact on expense ratio and the rating of the mutual funds. Turnover ratio and risk increase expense ratio. Number of holdings, size and allocation tend to reduce expense ratio. Allocation to North America and emerging markets both reduce rating. Expense ratio itself reduces rating.

Index funds try to mimic some established indices in the market and as such follow more passive strategy. The finding that managerial tenure positively influences the returns of index funds is a stronger result than the 
findings of previous studies that mix different sample characteristics. However, we recommend similar analysis for different types of mutual funds to ascertain this and document cross-sectional variations by fund characteristics.

\section{AUTHOR INFORMATION}

Demissew Diro Ejara is Associate Professor of Finance and Director of the Samuel S. Bergami Learning Center for Finance and Technology. Dr. Ejara completed his PhD in Finance from the University of Connecticut in 1998 and held faculty positions at the University of Massachusetts Boston and William Paterson University of New Jersey. Dr. Ejara's researches focus on corporate finance, international finance, financial markets, and securities issuance. He published papers in Journal of Banking and Finance, Management Decision, Multinational Finance Journal and International Business \& Economics Research Journal.

Raja Nag is Professor of Finance at the School of Management, New York Institute of Technology. His research interests include SEOs, IPOs, REITs, asset valuation, and corporate finance. He has published papers in Real Estate Economics, Journal of Real Estate Finance \& Economics, Real Estate Finance, Journal of Real Estate Portfolio Management, Journal of Business and Economics Research, and Journal of Applied Business Research.

\section{REFERENCES}

1. Chevalier, J., and Ellison, G. (1999) "Are Some Mutual Fund Managers Better Than Others? CrossSectional Patterns in Behavior and Performance" Journal of Finance, Vol. 54, pp. 875-899.

2. Ferreira, M.A., Miguel, A.F. and Ramos, S. (2006) "The Determinants of Mutual Fund Performance: A Cross-Country Study." Swiss Finance Institute Working paper.

3. Filbeck, G. and Tompkins, D.L. (2004) "Management tenure and Risk-Adjusted Performance of Mutual Funds." Journal of Investing, Vol. 13, pp. 72-80.

4. $\quad$ Fortin, R., Michelson, S. and Jordan-Wagner, J. (1999) "Does Mutual Fund Manager Tenure Matter?" Journal of Financial Planning, Vol. 12, No.7, pp. 72-79.

5. Haugen, Robert A. (1999) The New finance: the Case Against Efficient Markets, Second Edition, Prentice Hall, Upper Saddle River, New Jersey.

6. Peterson, J., Pietranico, P., Riepe, M. and Xu, F. (2001) "Explaining the Performance of Domestic Equity Mutual Funds" Journal of Investing, Vol. 10, pp. 81-92. 
Table 1

Descriptive Statistics

\begin{tabular}{|c|c|c|c|c|c|c|}
\hline Item Description & $\mathbf{N}$ & Mean & Median & Std. Deviation & Minimum & Maximum \\
\hline Total Return Annualized 3 Yr (\%) & 772 & 11.85 & 10.11 & 6.16 & -6.08 & 46.25 \\
\hline Total Return Annualized 5 Yr (\%) & 670 & 9.12 & 7.00 & 5.56 & -6.02 & 37.83 \\
\hline Total Return Annualized 10 Yr (\%) & 252 & 8.57 & 7.98 & 2.61 & -0.54 & 18.31 \\
\hline Investor Return Annualized 3 Yr \%) & 466 & 11.49 & 9.99 & 5.78 & 0.60 & 36.50 \\
\hline Investor Return Annualized 5 Yr (\%) & 381 & 9.46 & 8.29 & 5.94 & -16.39 & 30.59 \\
\hline Investor Return Annualized 10 Yr (\%) & 121 & 7.71 & 6.74 & 4.02 & -0.72 & 21.80 \\
\hline Audited Expense Ratio (\%) & 884 & 0.65 & 0.51 & 0.58 & 0.00 & 4.46 \\
\hline Turnover Ratio (\%) & 879 & 56.02 & 14.00 & 155.92 & 0.00 & 1299.00 \\
\hline P/E Ratio & 961 & 18.05 & 16.90 & 4.18 & 7.60 & 40.00 \\
\hline P/B Ratio & 968 & 2.85 & 2.80 & 0.62 & 0.60 & 5.40 \\
\hline Mstar Rating & 770 & 2.95 & 3.00 & 0.87 & 1.00 & 5.00 \\
\hline Std. Deviation 3 Yr (\%) & 772 & 9.61 & 8.71 & 3.83 & 0.76 & 29.01 \\
\hline Std. Deviation 5 Yr (\%) & 670 & 13.70 & 12.99 & 4.14 & 0.79 & 39.24 \\
\hline Std. Deviation 10 Yr (\%) & 252 & 15.19 & 15.19 & 5.77 & 0.82 & 42.40 \\
\hline Net Assets \$MM & 1064 & 1213.63 & 114.25 & 4602.43 & 0.00 & 70352.60 \\
\hline Total Number of Holdings & 1073 & 582.79 & 403.00 & 931.20 & 1.00 & 10465.00 \\
\hline$\%$ Assets in Top 10 Holdings & 1080 & 32.84 & 21.35 & 26.21 & 2.04 & 100.00 \\
\hline$\%$ Cash & 1073 & 5.42 & 0.60 & 17.18 & 0.00 & 100.00 \\
\hline$\%$ US Stocks & 1073 & 69.92 & 96.60 & 42.06 & 0.00 & 100.00 \\
\hline$\%$ Non-US Stocks & 1073 & 16.65 & 0.00 & 34.79 & 0.00 & 100.00 \\
\hline$\%$ Bonds & 1073 & 5.92 & 0.00 & 22.47 & 0.00 & 100.00 \\
\hline$\%$ Other & 1073 & 2.10 & 0.00 & 9.14 & 0.00 & 100.00 \\
\hline$\%$ North America & 968 & 81.20 & 100.00 & 37.16 & 0.00 & 100.00 \\
\hline Market Maturity \% Developed & 968 & 98.34 & 100.00 & 10.37 & 0.00 & 100.00 \\
\hline Market Maturity \% Emerging & 968 & 1.66 & 0.00 & 10.38 & 0.00 & 100.00 \\
\hline Manager Tenure (Average) & 1096 & 2.94 & 2.00 & 3.14 & 0.00 & 15.30 \\
\hline
\end{tabular}


Table 2

Averages by Quartiles of Managerial Tenure

\begin{tabular}{|c|c|c|c|c|c|c|c|}
\hline Item Description & $\begin{array}{c}\text { 1st } \\
\text { Quartile }\end{array}$ & $\begin{array}{c}\text { 2nd } \\
\text { Quartile }\end{array}$ & $\begin{array}{c}\text { 3rd } \\
\text { quartile }\end{array}$ & $\begin{array}{c}\text { 4th } \\
\text { Quartile } \\
\end{array}$ & $\begin{array}{l}\text { Stat } \\
\text { Sig. }\end{array}$ & $\begin{array}{c}\text { Total } \\
\text { Sample } \\
\end{array}$ & $\mathbf{N}$ \\
\hline Total Return Annualized $3 \operatorname{Yr}(\%)$ & 11.419 & 13.310 & 10.884 & 11.889 & $* * *$ & 11.797 & 759 \\
\hline Total Return Annualized 5 Yr (\%) & 8.909 & 9.609 & 8.399 & 9.482 & & 9.118 & 661 \\
\hline Total Return Annualized 10 Yr (\%) & 7.923 & 8.948 & 7.770 & 8.701 & $*$ & 8.552 & 249 \\
\hline Investor Return Annualized 3 Yr (\%) & 9.736 & 11.225 & 11.413 & 11.885 & & 11.422 & 463 \\
\hline Investor Return Annualized 5 Yr (\%) & 8.808 & 8.383 & 10.314 & 9.288 & & 9.372 & 378 \\
\hline Investor Return Annualized 10 Yr (\%) & 5.000 & 6.977 & 6.945 & 8.176 & & 7.670 & 120 \\
\hline Audited Expense Ratio (\%) & 0.934 & 0.468 & 0.697 & 0.671 & $* * *$ & 0.658 & 871 \\
\hline Turnover Ratio (\%) & 147.219 & 22.130 & 81.596 & 25.620 & $* * *$ & 56.723 & 866 \\
\hline P/E Ratio & 18.114 & 17.833 & 18.036 & 18.064 & & 18.003 & 931 \\
\hline P/B Ratio & 2.922 & 2.873 & 2.857 & 2.724 & $* * *$ & 2.841 & 938 \\
\hline Mstar Rating & 2.737 & 3.088 & 2.891 & 3.000 & $* *$ & 2.955 & 757 \\
\hline Std. Deviation 3 Yr (\%) & 9.729 & 9.593 & 9.755 & 9.409 & & 9.598 & 759 \\
\hline Std. Deviation 5 Yr (\%) & 13.657 & 13.987 & 14.074 & 13.249 & & 13.698 & 661 \\
\hline Std. Deviation 10 Yr (\%) & 15.185 & 17.831 & 13.114 & 14.733 & $* * *$ & 15.175 & 249 \\
\hline Net Assets \$MM & 100.591 & 1918.129 & 914.097 & 1565.266 & $* * *$ & 1127.783 & 1008 \\
\hline Total Number of Holdings & 361.201 & 588.469 & 688.544 & 740.772 & $* * *$ & 608.592 & 1023 \\
\hline$\%$ Assets in Top 10 Holdings & 31.214 & 31.117 & 30.388 & 29.536 & & 30.522 & 1030 \\
\hline$\%$ Cash & 3.719 & 4.990 & 5.982 & 2.845 & * & 4.436 & 1023 \\
\hline$\%$ US Stocks & 69.551 & 71.024 & 70.454 & 73.847 & & 71.307 & 1023 \\
\hline$\%$ Non-US Stocks & 19.936 & 19.762 & 14.147 & 13.188 & $* *$ & 16.578 & 1023 \\
\hline$\%$ Bonds & 6.340 & 2.332 & 7.684 & 8.545 & $* * *$ & 6.206 & 1023 \\
\hline$\%$ Other & 0.458 & 1.896 & 1.735 & 1.582 & * & 1.477 & 1023 \\
\hline$\%$ North America & 78.084 & 79.271 & 83.045 & 85.239 & & 81.559 & 938 \\
\hline Market Maturity \% Developed & 98.735 & 97.918 & 98.848 & 98.187 & & 98.399 & 938 \\
\hline Market Maturity \% Emerging & 1.265 & 2.082 & 1.153 & 1.814 & & 1.601 & 938 \\
\hline Manager Tenure (Average) & 0.400 & 1.315 & 2.763 & 7.300 & $* * *$ & 2.945 & 1096 \\
\hline
\end{tabular}

$* * *, * *$ and $*$ indicate statistical significance of inter-quartile mean differences at $1 \%, 5 \%$ and $10 \%$ levels respectively. 
Table 3

Regression of Performance on Managerial Tenure (Estimation of Equation 1)

\begin{tabular}{|l|r|r|r|}
\hline \multicolumn{1}{|c|}{ Variable } & 3 yr. Ann. Return & 5 yr. Ann. Return & 10 yr. Ann. Return \\
\hline Constant & $18.52963 * * *$ & $10.24948 * * *$ & $2.078965 * * *$ \\
Std Dev 3 Yr & $0.54336 * * *$ & $0.65299 * * *$ & $0.611129 * * *$ \\
Total Number of Holdings & -0.00003 & $0.00052^{* * *}$ & $0.000256^{*}$ \\
\% Assets in Top 10 Holdings & -0.00369 & -0.00352 & $0.031184 * * *$ \\
Turnover Ratio & $-0.00354 * *$ & $-0.00476 * *$ & -0.017019 \\
P/E Ratio & $-0.27307 * * *$ & $-0.11440 * *$ & -0.054883 \\
\% North America & $-0.08211^{* * *}$ & $-0.07814 * * *$ & $0.016798 * * *$ \\
Market Maturity \% Emerging & $0.08126 * * *$ & $0.04507 * * *$ & $-0.050014 * * *$ \\
Net Assets \$MM & 0.00004 & 0.00004 & 0.000002 \\
Manager Tenure (Average) & $0.10918 * *$ & $0.20313 * * *$ & 0.046876 \\
\hline \multicolumn{2}{|c|}{} & & \\
N & 606 & 532 & 192 \\
R-Square & $62.6 \%$ & $63.4 \%$ & $47.7 \%$ \\
Adjusted R-Square & $62.0 \%$ & $62.8 \%$ & $45.1 \%$ \\
\hline
\end{tabular}

$* * *, * *$ and $*$ indicate statistical significance at $1 \%, 5 \%$ and $10 \%$ levels respectively.

Table 4

Regressions of Audited Expense Ratio and Morningstar Rating (Estimations of Equations (2) and (3))

\begin{tabular}{|l|r|r|}
\hline \multicolumn{1}{|c|}{ Variable } & Audited Expense Ratio & \multicolumn{1}{c|}{ Morningstar Rating } \\
\hline Constant & $0.686281 * * *$ & $3.954901 * * *$ \\
Std Dev 3 Yr & $0.013722 *$ & -0.004467 \\
Total Number of Holdings & $-0.000074 * * *$ & $0.000141 * * *$ \\
\% Assets in Top 10 Holdings & 0.001835 & -0.001397 \\
Turnover Ratio & $0.001379 * * *$ & 0.000230 \\
P/E Ratio & -0.000097 & -0.009688 \\
\% North America & $-0.002398 * * *$ & $-0.005473 * * *$ \\
Market Maturity \% Emerging & $-0.005820 * *$ & $-0.011440 * * *$ \\
Net Assets \$MM & $-0.000018 * * *$ & 0.000002 \\
Manager Tenure (Average) & -0.000889 & 0.012215 \\
Audited Expense Ratio & & $-0.661148 * * *$ \\
\hline & & 602 \\
N & $23.0 \%$ & $21.8 \%$ \\
R-Square & & $28.9 \%$ \\
Adjusted R-Square & & $27.7 \%$ \\
\hline
\end{tabular}

***,** and * indicate statistical significance at $1 \%, 5 \%$ and $10 \%$ levels respectively. 
Figures 1 \& 2 Mutual Fund Return and Managerial Tenure
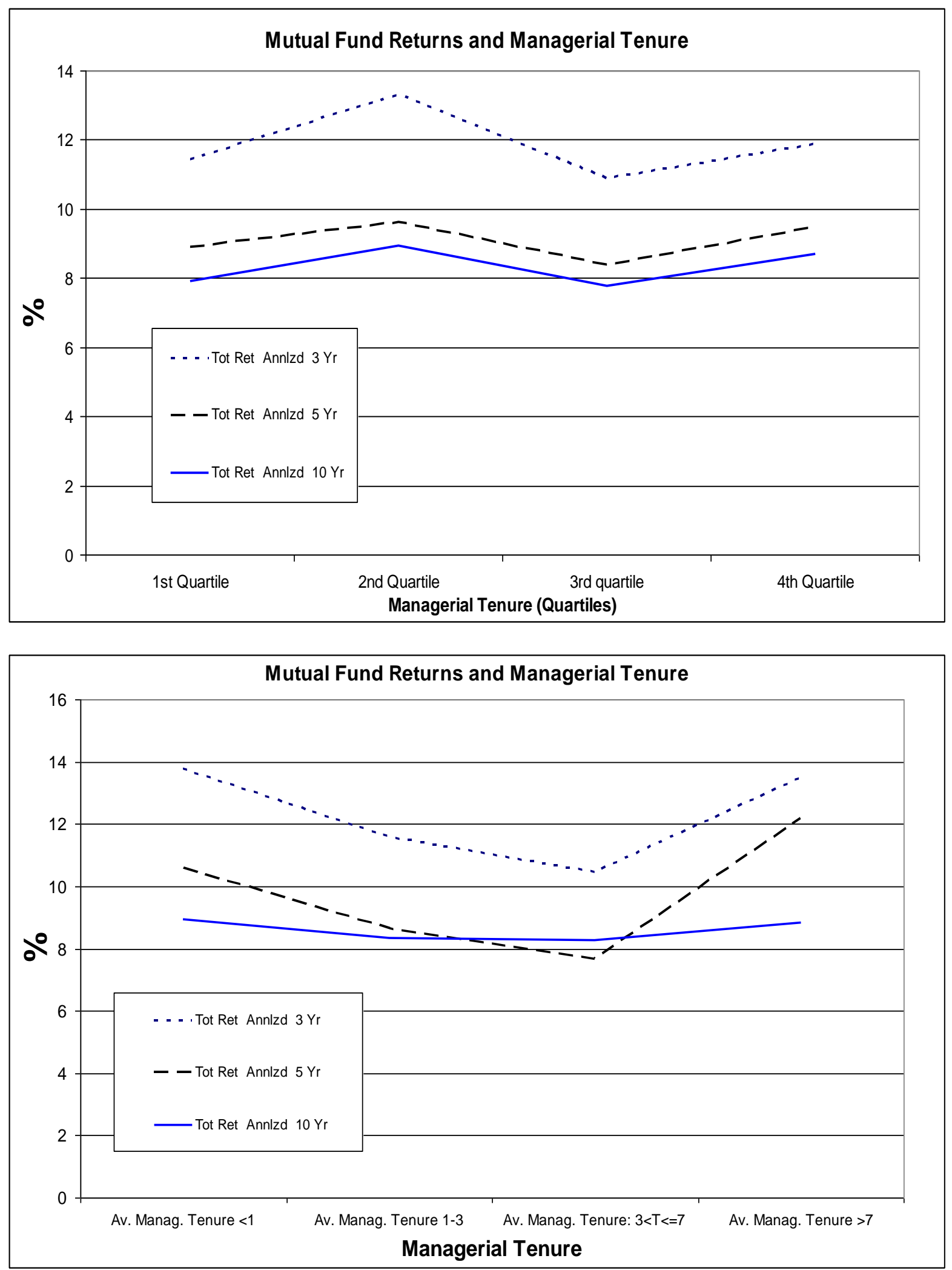
NOTES 